\title{
Genetic resistance spreads to consumers
}

Washington. A small Iowa company that produces a test able to detect genetic alterations in crops is being deluged with calls as wary European consumers and retailers react to the news that genetically modified corn (maize) and soybeans are being harvested in the United States for the first time.

"There has been tremendous interest," says Jeff Wells, who helped to found Genetic ID only two months ago. "It's the European export trade that's interested," he adds, pointing out that it's "not just health food people [but] general consumers".

According to Wells, orders from corn and soy brokers on both sides of the Atlantic have already pushed his firm to capacity. The firm sells tests that can detect the genetic alterations in engineered soybeans and corn produced in the United States by Monsanto and Ciba-Geigy respectively.

Both crops are genetically altered to resist herbicides made respectively by Monsanto and AgrEvo, a Frankfurt chemical company. The corn is also altered to resist the European corn borer, by insertion of a gene from a bacterium called Bacillus thuringiensis, which makes a protein toxic to the pest.

Both the soybeans and the corn have been passed as safe by the governments of the United States, Canada and Japan. The European Union (EU) has approved the soybeans for import and processing, but similar approval of the corn is bogged down in committees in Brussels.

Genetic ID's new tests allow middlemen who funnel exports of corn and soy from the United States to European clients to guarantee that the crops are free of genetically altered product - a guarantee that many European retailers are now demanding.

In a separate move, one of the largest US soybean processing companies has begun segregating soybeans. Last month, Central Soya Co of Fort Wayne, Indiana, acknowledged
Growing problem? Some European consumers are worried about the safety of genetically altered corn.
At the same time, an international coalition led by consumer activist Jeremy Rifkin announced a boycott of the corn and soybeans, focusing on ten companies which the coalition will pressure to guarantee that certain foods are free of the geneticallyaltered crops and their derivatives.

The campaign comes amid rumblings of a possible 'corn war' between the United States and Europe. Even as European consumer resistance has mounted to the EU's April decision to allow the import of the soybeans, European countries have divided over whether to allow the import of Ciba-Geigy's genetically engineered corn.

After the EU's Council of Environmental Ministers failed to approve the corn in June, the issue was referred to three scientific committees of the European Commission (EC). It is not known when these committees - on food, animal nutrition, and pesticides - will make their recommendations.

But the first corn grown from the genetically engineered seeds is already being harvested in the United States, and exports to Europe usually start in November. Unless the EC issues rapid approval, imports would violate EU rules.

Ciba says that the corn -1 to 2 per cent $\vec{a}$ of the expected US harvest - cannot practically \% be separated from nongenetically engineered corn. This raises the possibility that Europe would need to ban all US corn imports - valued at US\$500 million in 1995 — to bar the geneticallyengineered variety.

Without a European decision soon, "there could be serious trade repercussions", says a senior official at the US Department of Agriculture (USDA).

US officials have dismissed as irrational European concern about the safety of both the corn and the soybeans, and have called impracticable demands for their segregation and labelling.

Paul Drazek, senior that it had barred deliveries of genetically engineered soybeans to one of its seven US granaries.

According to surveys, up to 85 per cent of European consumers would shun genetically altered foods if given a choice. EuroCommerce, a trade group representing onethird of EU food wholesalers and retailers, demanded here last week that US exports of Monsanto's soybeans be labelled. trade adviser to agriculture secretary Dan Glickman, recently called the soybeans "absolutely safe", and said segregation or labelling make "no scientific sense". At meetings last week in Brussels, Drazek pressed EU officials to speed approval of the Ciba corn, afterwards stating that "there are a lot of people in Europe who understand the importance of these new technologies to world agriculture".
Arnold Foudin, deputy director of biotechnology, biologics and environmental protection at USDA, said last month that the Ciba corn presents "an opportunity to displace a system [of pesticide use] which may be 100 times more damaging".

But European countries have raised concerns about the corn. Last spring, Austria, Denmark and Sweden raised worries about its environmental effects, including the development of pest resistance to the toxin produced by the corn.

They also worried that the corn's herbicide resistance gene might jump to neighbouring weedy relatives. And they complained that the imports ought at least to be labelled as genetically engineered. Consumer activists argue that labelling would protect against unidentified allergens possibly carried by both crops.

Britain raised separate concerns over the fact that the corn carries a marker gene conferring resistance to beta-lactam antibiotics including ampicillin, which is used widely in people and animals. The UK's Advisory Committee on Novel Foods and Processes (ACNFP) has declared that this poses an "unacceptable risk", as bacteria in the guts of animals eating the unprocessed corn could take up the gene.

Ciba disputes all these charges. "We know, and the most stringent review processes from [three] nations confirm, that $B t$ corn is safe for humans, animals and the environment," says Rich Lotstein, director of regulatory affairs at Ciba Seeds, a division of Ciba-Geigy.

Some prominent scientists, whose opinions were solicited by the company, concur. "There is no scientific data" indicating that DNA could jump from a food to a microbe in the gut of an animal, wrote Roger Beachy, the head of the Division of Plant Biology at Scripps Research Institute in La Jolla, California. He concluded that transgenic foods "pose no risk to the public, nor to the farm animals for which they serve as food".

A Monsanto spokeswoman said that the firm's soybeans have been found safe "around the world", including Japan, Mexico and Argentina. "These are just soybeans, the same as other soybeans, and that's why no special handling or labelling is required," said Karen Marshall.

The huge, St. Louis-based company is evidently undeterred by the controversy. Even as Greenpeace activists sprayed one of its Iowa soybean fields with a giant pink ' $X$ ' last Thursday, Monsanto announced that it is considering selling off its \$3.7-billion chemical unit, leaving it better placed to concentrate on its lucrative agricultural biotechnology products - including soybeans. The company's stock rose $\$ 0.50$ on the news, to $\$ 41.13$. It has gained almost 70 per cent this year. 